\title{
Evaluation of the Prevalence and Distribution of Congenital Heart Diseases Who Presented to a Pediatric Cardiology Outpatient Clinic
}

\section{Çocuk Kardiyoloji Kliniğine Başvuran Çocuklarda Konjenital Kalp Hastalığı Sıklığının ve Dağılımının Değerlendirilmesi}

\author{
(1) Hanife Tuğçe Çağlar', (연 Ahmet Sert ${ }^{2}$ \\ 'Ortaköy State Hospital, Department of Pediatrics, Aksaray, Turkey \\ ${ }^{2}$ Selcuk University School of Medicine Department of Pediatrics, Division of Pediatric Cardiology, Konya, Turkey
}

Öz

Amaç: Çocuk kardiyoloji kliniğine başvuran hastalarda konjenital kalp hastalığı sıklığının ve dağılımının belirlenmesi amaçlandı.

Gereç ve Yöntem: Çocuk Kardiyoloji kliniğinde Ocak 2013-Aralık 2015 tarihlerinde 3 yıllık periyodda transtorasik ekokardiyografi ile değerlendirilen çocukların dosya kayıtları geriye dönük olarak incelendi. Konjenital kalp hastalıkları soldan sağa şantlı hastalıklar, obstrüktif hastalıklar, siyanotik hastalıklar, kardiyak malpozisyon, vasküler ring ve sınıflandırılmayan hastalıklar olmak üzere gruplandırıldı. Hastalıkların sıklığı, cinsiyet ve yaş grupları arası dağılımı incelendi.

Bulgular: Çalışmaya 12.342 birey dahil edildi. Çalışma bireylerinin 6996'si erkek (\%56,7), 5346'si kız (\%43,3) idi. Bireylerin yaş aralığı 1 gün - 18 yıl, ortanca yaş 7 yıl (IQR:10.5) idi. Konjenital kalp hastalığı tüm bireylerin \%27,7'sinde tespit edildi. Konjenital kalp hastalığı erkeklerde ve 0-1 ay yaş grubunda en sık saptandı. Konjenital kalp hastalıkları sırasıyla \%87 soldan sağa şantlı hastalıklar, $\% 21,2$ sınıflandırılmayan hastalıklar, \%7 obstrüktif hastalıklar, $\% 1,6$ siyanotik hastalıklar, \%0,8 vasküler ring ve \%0,7 kardiyak malpozisyon olarak tespit edildi.

Sonuç: Çocuk kardiyoloji kliniğine başvuran bütün çocuklara ekokardiyografi yapılmasını öneriyoruz çünkü bu çocukların dörtte birinde konjenital kalp hastalığı tespit edildi. Yaşamın ilk bir ayında çocuk kardiyoloji bölümüne yönlendirilen yenidoğanlara ekokardiyografik inceleme yapılması ile özellikle soldan sağa şantlı ve siyanotik konjenital kalp hastalıklarının tespit edilmesi ve böylece bunların uygun zamanda tedavilerinin planlanması sağlanacaktır.

Anahtar Sözcükler: Çocukluk çağı, konjenital kalp hastalığı, prevalans

\begin{abstract}
Aim: The present study aimed to determine the prevalence and distribution of congenital heart disease in patients who presented to the pediatric cardiology clinic.

Material and Method: File records of the children who underwent transthoracic echocardiography within the 3-year period between January 2013 and December 2015 at the pediatric cardiology clinic were retrospectively evaluated. Congenital heart diseases were grouped as follows: diseases with a left-to-right shunt, obstructive diseases, cyanotic diseases, cardiac malposition, vascular ring and unclassified diseases. Prevalence of the diseases, distribution among gender and age groups were investigated.

Results: This study included 12,342 subjects; 6996 (56.7\%) subjects were male and 5346 (43.3\%) subjects were female. The subjects were aged between 1 day and 18 years, and the median age was 7 years (IQR:10.5); $27.7 \%$ of the subjects were determined to have congenital heart disease. The prevalence of congenital heart disease was higher in males and in the 0-1 month age group. Of the subjects with congenital heart disease, $87 \%$ had a disease with a left-to-right shunt $21.2 \%$ had an unclassified disease, $7 \%$ had obstructive disease, $1.6 \%$ had cyanotic disease, $0.8 \%$ had a vascular ring and $0.7 \%$ had cardiac malposition.

Conclusion: We recommend performing echocardiography in all children who presented to the pediatric cardiology clinic because one-fourth of these children have congenital heart disease. Conducting echocardiographic examination on new-borns who are referred to the pediatric cardiology department within the first month of life would enable detecting, particularly the diseases with a left-toright shunt and cyanotic congenital heart diseases, and ensure timely treatment planning.
\end{abstract}

Keywords: Childhood, congenital heart diseases, prevalence 


\section{INTRODUCTION}

The prevalence of congenital heart disease (CHD) is 8 per 1000 live births. The disease is the most common cause of prenatal mortality. ${ }^{[1,2]}$ Therefore, early diagnosis and timely treatment are vital for CHD. The prevalence of CHD varies by age, continents and countries. According to a recent study conducted in Canada, the recent prevalence of CHD was higher than the previous years (13.1 per 1000 live births). ${ }^{[3]}$ A limited number of studies exist on the distribution of CHD in Turkey. ${ }^{[4-6]}$ Our study aimed to investigate the prevalence and distribution of CHD and comorbidities in children who underwent transthoracic echocardiography between January 2013 and December 2015 at the pediatric cardiology clinic.

\section{MATERIAL AND METHOD Subjects}

Subjects included in this retrospective study consisted of individuals between the ages 1 day-18 years, which presented to the pediatric cardiology outpatient clinic of our hospital within the 3-year period between January 2013 and December 2015 and underwent transthoracic echocardiography upon their first admission. In addition to outpatients; patients consulted by newborn intensive care unit were included in the study. Patients consulted from other departments and patients with missing data were excluded from the study. In addition, patients older than 18 years and premature neonates who had patent ductus arteriosus (PDA) were excluded from the study.

Approval for the study was obtained from the Ethics Committee of Necmettin Erbakan University Meram Faculty of Medicine with decision no. 2015/224.

Patient demographics and diagnoses according to the transthoracic echocardiograms at the time when patients first presented were obtained from patient records. Patients divided into 4 groups according to their ages (0-1 month, 1 month-2 years, 2-6 years and 6-18 years).

Patients were classified according to their diseases as follows: diseases with a left-to-right shunt, obstructive lesions, cyanotic heart defects, vascular rings, cardiac malposition and unclassified diseases. ${ }^{[7]}$ Ventricular septal defects (VSD) classified as perimembranous (inlet, outlet, trabecular), muscular and doubly commited. ${ }^{\left[{ }^{[8]}\right.}$

\section{Echocardiographic Examination}

All transthoracic echocardiographic examinations were conducted by a single pediatric cardiologist. All subjects included in the study underwent two-dimensional, M-mode, colour and pulsed-wave Doppler echocardiography. ProSound Alpha 7 Aloka (Hitachi-Aloka Medical, Tokyo, Japan) was used for echocardiography.

\section{Statistical Analysis}

Statistical analysis was performed using Statistical Package for the Social Sciences software (version 18). Descriptive statistical methods (percentage calculations, median, mean, standard deviation) were used when evaluating the study data. Visual and analytical methods (Kolmogorov-Smirnov/Shapiro-Wilk's tests) were used to determine if the variables showed normal distribution. Descriptive analyzes are expressed as mean \pm SD for variables showing normal distribution and as median and interquartile range (IQR) for those lacking normal distribution. In comparisons between groups; Chi-square test was used for categorical variables. Situations where the $p$-value was below 0.05 were evaluated as statistically significant results.

\section{RESULTS}

A total of 12342 subjects were included in the study, of which 6996 subjects (56.7\%) were male and 5346 subjects (43.3\%) were female. The patients were aged between 1 day and 18 years; the the median age was 7 (IQR:10.5) years.

Of all the subjects, $54.9 \% \quad(n=6774)$ had normal echocardiographic findings, whereas $45.1 \%(n=5568)$ had abnormal echocardiographic findings. Of the subjects with abnormal echocardiographic findings, 3418 were included in the CHD classification. 632 patients classified in CHD had two or more combined defects and they included in different subgroups for each defect. Other 2150 subjects had different diagnosis that were not evaluated in CHD such as mitral valve prolapse, patent foramen ovale (PFO) or bicuspid aortic valve. Diagnosis and gender distributions of the subjects and comprasions of gender were presented in Table 1.

Table 1. Diagnosis distributions and gender comparisons of the subjects

\begin{tabular}{|lcccc|}
\hline & $\mathbf{n}$ & $\begin{array}{c}\text { Prevalence } \\
\text { in CHDs, } \%\end{array}$ & $\begin{array}{c}\text { Prevalence } \\
\text { in the } \\
\text { study, } \%\end{array}$ & $\begin{array}{c}\text { Male, } \\
\%\end{array}$ \\
\hline All CHDs & 3418 & 100 & 27.7 & 53.5 \\
$\begin{array}{l}\text { Diseases with a left-to- } \\
\text { right shunt }\end{array}$ & 2975 & 87 & 24.1 & 52.9 \\
ASD & 2435 & 71.2 & 19.7 & 52.5 \\
VSD & 455 & 13.3 & 3.7 & 49.2 \\
PDA & 498 & 14.5 & 4 & 52.2 \\
AVSD & 24 & 0.7 & 0.2 & 37.5 \\
PAPVR & 10 & 0.2 & 0.1 & 70 \\
Obstructive diseases & 239 & 7 & 1.9 & 56.9 \\
Pulmonary stenosis & 135 & 3.9 & 1.1 & 43.7 \\
Aortic stenosis & 81 & 2.3 & 0.7 & 77.8 \\
Coarctation of the aorta & 28 & 0.8 & 0.2 & 60.7 \\
Interrupted aortic arch & 2 & 0.06 & 0.01 & \\
Cyanotic heart diseases & 55 & 1.6 & 0.4 & 50.9 \\
Cardiac malposition & 26 & 0.7 & 0.2 & 73.1 \\
Vascular ring & 30 & 0.8 & 0.2 & 50 \\
Unclassified Diseases & 725 & 21.2 & 5.9 & 47.7 \\
\hline $\begin{array}{l}\text { ASD: atrial septal defect, AVSD: atrioventricular septal defect, CHD: Congenital Heart Diseases, PAPVR: } \\
\text { partial anomalous pulmonary venous } \\
\text { defect. }\end{array}$ & & & & \\
\hline
\end{tabular}


Cyanotic Diseases: Of the subjects included in the study; $0.1 \%(n=7)$ had transposition of the great arteries (TGA), $0.2 \%$ $(n=20)$ had tetralogy of Fallot, 3 had corrected-TGA, 1 had total anomalous pulmonary venous return (TAPVR), 3 had tricuspid atresia, 4 had pulmonary atresia, 1 had hypoplastic left heart syndrome, 1 had Ebstein anomaly, 4 had double outlet right ventricle, 1 had heterotaxia, 2 had tricuspid atresia accompanied with pulmonary atresia, 6 had pulmonary atresia accompanied by tetralogy of Fallot and 2 had corrected TGA accompanied with pulmonary atresia.

Vascular Rings: Of the subjects included in the study; $0.2 \%$ $(n=22)$ had right-sided aortic arch accompanied by left ligamentum arteriosum, 1 had double aortic arch, 1 had aberrant innominate artery, 2 had aberrant right subclavian artery, 3 had abnormal left pulmonary artery and 1 had right-sided aortic arch accompanied by abnormal left pulmonary artery. In addition to echocardiography, cardiac computed tomography imaging was used in the diagnosis of these patients. 1 double aortic arch, 2 of right-sided aortic arch accompanied by left ligamentum arteriosum and 2 of abnormal left pulmonary arteries were isolated defects. Other 25 patients had another CHD (7 Cardiac Malposition, 7 tetralogy of Fallot, 3 pulmonary atresia, 1 TGA, 11 ASD, 7 VSD, 3 PDA, 1 PAPVD).

Cardiac Malposition: Of the subjects included in the study; $0.2 \%(n=19)$ had dextrocardia and $0.1 \%(n=7)$ had mesocardia.

Unclassified Diseases: Of the subjects included in the study; $0.1 \%(n=13)$ had coronary AV fistula, 1 had pulmonary AV fistula, 1 had systemic AV fistula, 0.6\% $(n=70)$ had atrial septal aneurysm, 4 had double chambered right ventricle, $0.1 \%$ $(n=10)$ had idiopathic dilatation of the pulmonary artery, 1 had pseudo coarctation of the aorta, $0.1 \%(n=16)$ had systemic venous anomaly, $4.7 \%(n=583)$ had peripheral pulmonary stenosis, $0.1 \%(n=7)$ had atrial septal aneurysm accompanied by peripheral pulmonary stenosis, 1 had hemitruncus arteriosus accompanied with peripheral pulmonary stenosis, 5 had aortopulmonary collateral artery (APCA), $0.1 \%(n=10)$ had major aortopulmonary collateral artery (MAPCA), 2 had systemic venous anomaly accompanied by peripheral pulmonary stenosis, and 1 had atrial septal aneurysm accompanied by systemic venous anomaly. In addition to echocardiography, cardiac computed tomography imaging has also been used in the diagnosis of these patients. 1 systemic AV fistula and 1 pseudo coarctation of the aorta were isolated defects. All other patients in this group had another CHD.

4 age group compared in all subjects and CHDs were more common in subjects aged $0-1$ months $(p<0.001)$. Distribution of CHD according to age groups and their comprasions was presented in Table 2.

Of the diseases with a left-to-right shunt; $81.8 \%$ were atrial septal defects (ASDs), 15.3\% were ventricular septal defects (VSDs), $16.7 \%$ were PDAs, $0.8 \%$ was atrioventricular septal defect (AVSDs) and $0.3 \%$ was partial anomalous pulmonary venous return (PAPVR).

Of the ASDs, 98\% $(n=2385)$ were secundum ASDs, $0.2 \%(n=5)$ were isolated primum ASDs, $0.1 \%(n=3)$ were sinus venosus ASDs, $0.3 \%(n=8)$ were coronary sinus ASDs, and $1.3 \%(n=33)$ were operated upon ASDs. One subject had both primum and secundum ASDs.

Of the VSDs, $2.4 \%(n=11)$ were perimembranous inlet VSDs, $19.4 \%(n=88)$ were perimembranous outlet VSDs, $12.1 \%$ $(n=55)$ were perimembranous trabecular VSDs, $53.1 \%(n=242)$ were muscular VSDs, $1.1 \%(n=5)$ were doubly committed VSDs, $5.1 \%(n=23)$ were operated VSDs and $6.8 \%(n=31)$ were closed VSDs.

Of the obstructive diseases; $56.5 \%$ were pulmonary stenoses, $33.9 \%$ were aortic stenoses, $11.7 \%$ were coarctation of the aorta and $0.8 \%$ were interrupted aortic arch.

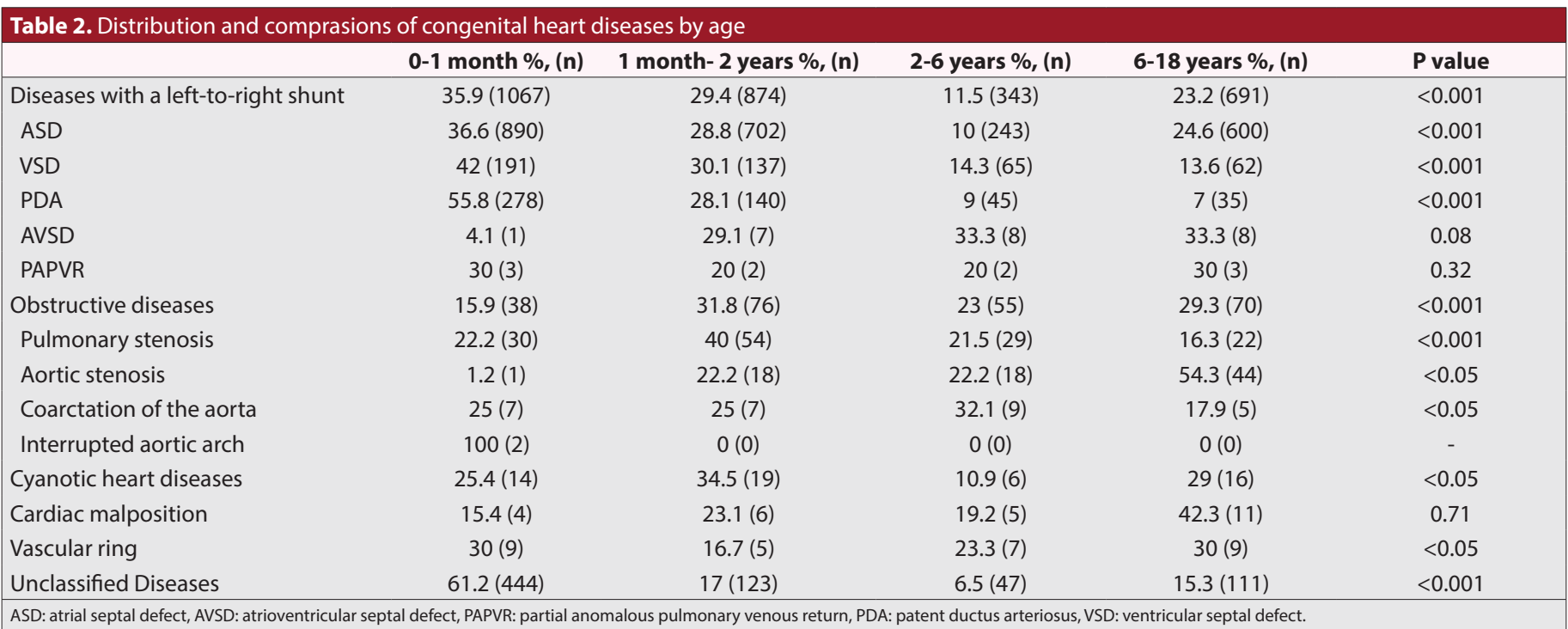


A total of $93.3 \%(n=126)$ of the pulmonary stenoses were valvular, $5.2 \%(n=7)$ were supravalvular and $2.5 \%(n=2)$ were subvalvular stenoses.

Of the aortic stenoses, $12.3 \%(n=10)$ were supravalvular stenoses, $60.5 \%(n=49)$ were valvular stenoses, $21 \%(n=17)$ were subaortic ridge without subaortic stenosis, $2.5 \%(n=2)$ were subaortic stenoses and $3.7 \%(n=3)$ were subaortic ridge accompanied by subaortic stenosis.

\section{DISCUSSION}

The prevalence of CHD varies by continents and countries. In a meta-analysis conducted in 2011 in the Netherlands, it was found that there were 1.35 million new-borns with CHD every year over the last 15 years, that the prevalence of CHD in Europe were significantly higher than that in Northern America, that the highest prevalence of $\mathrm{CHD}$ was observed in Asia $(9.3$ per 1000) and the lowest prevalence was observed in Africa (1.9 per 1000) and that the global prevalence of CHD increased from 0.6 per 1000 in 1930 to 9.1 per 1000 after 1995. ${ }^{[9]}$ The prevalence of $\mathrm{CHD}$ was found to be 8 per 1000 in studies conducted in Turkey, which is similar to the rates reported in the Western countries. ${ }^{[4-6]}$

In our retrospective study based on selected subjects, $27.7 \%$ of the subjects were diagnosed with CHD by echocardiography. This rate was higher in our study compared with that present the literature is because our study was not a populationbased study. Our hospital provides secondary and tertiary healthcare services. The most common causes for presenting to our pediatric cardiology outpatient clinic were murmurs and chest pain. Besides the individuals who present to our clinic as outpatients, new-borns who are suspicious in cardiac screening were also examined using echocardiography.

In our study, $46.1 \%$ of the subjects with CHD were $0-1$ month old and $87 \%$ of the subjects with CHD comprised those with diseases with a left-to-right shunt. A study conducted in 2007 showed that the prevalence of diseases with a left-to-right shunt was higher in girls than in boys. ${ }^{[10]}$ However, diseases with a left-to-right shunt were more common in boys (52.9\%) according to our study.

Egbe et al. ${ }^{[11]}$ reported that the frequency of ASD within CHDs was $15.6 \%$, whereas Kula et al. ${ }^{[12]}$ reported the same to be $11.1 \%$ in Turkey. Our study showed that $19.7 \%$ of all subjects and $71.2 \%$ of the subjects with CHD had ASD. This is because the subjects included in this study were selected from individuals who presented to the cardiology outpatient clinic and that ASD closure can be observed in time. Our clinic provides the opportunity of echocardiographic examination within the first days of life for neonates who cannot pass new-born screening. Therefore, it is possible that secundum ASD could not be distinguished from patent foramen ovale (PFO) due to the presence of left atrial flap tissue during echocardiographic examination and the defects that appeared larger than $3 \mathrm{~mm}$ in colour Doppler were classified as secundum ASD.
In our study, ASD was more common in 0-1-month-old subjects. Previous studies showed that ASD was more common in girls, whereas the prevalence of ASD was slightly higher in boys according to our study. ${ }^{[13]}$ It was reported in the literature that $75 \%$ of the ASDs were secundum, $15 \%$ were primum and $10 \%$ were sinus venosus ASDs. ${ }^{[14]}$ In our study, $98 \%$ of the ASDs were secundum, $0.2 \%$ were primum, $0.1 \%$ were sinus venosus, $0.3 \%$ were coronary sinus and $1.3 \%$ were operated upon ASDs. We think that the prevalence of secundum ASD is higher than the literature since the subjects in 0-1 month group are very much in our study (\%12.7 in whole study). The prevalence of primum ASD in our study appears to be less than the literature. Primum ASDs are often observed as a component of AVSD. We included these patients in the AVSD classification and did not specify them as primum ASD.

Van der Linde et al. ${ }^{[8]}$ reported a worldwide VSD prevalence of 2.62 per 1000 live births, and stated that VSDs constituted $34 \%$ of all CHDs. In our study, the prevalence of VSD was 3.7\% in all subjects and $13.3 \%$ of all CHDs were VSDs, which was a relatively lower rate. Holst et al. ${ }^{[15]}$ reported that VSD was more common in girls $(52.5 \%)$ than boys. Similarly, our study also showed that VSD was more common in girls (50.8\%) than boys (49.2\%). In addition, VSD was more common in 0-1-month-old subjects. In a study conducted in 2011, it was reported that $70 \%$ of VSDs were perimembranous VSDs. ${ }^{[16]}$ On the contrary, most of the VSDs were muscular VSDs $(53.1 \%)$ in our study, whereas perimembranous VSDs constituted $40 \%$ of all VSDs.

The frequency of PDA in CHDs was reported to be $15.9 \%$ in Turkey by Başpınar et al. ${ }^{[17]}$ and $15.8 \%$ in Saudi Arabia by Abbag et al. ${ }^{[18]}$ Our study showed that the frequency of PDA in CHDs was $14.5 \%$, which was similar to the values reported in the literature. We excluded the preterm neonates with PDA. In our study, the mean age at the time of PDA diagnosis was 1.2 years and $55.8 \%$ of the PDAs were observed in $0-1$-monthold subjects. Although numerous studies reported that the prevalence of PDA was nearly twofold higher in girls than boys, $52 \%$ of the subjects with PDA were boys in our study.

AVSD represents around $3 \%$ of CHDs. ${ }^{[19]}$ In our study, the frequency of AVSD in CHDs was $0.7 \%$.

The prevalence of PAPVR was reported to be $0.1 \%$ by Ho et al. ${ }^{[20]}$ In our study, the prevalence of PAPVR was $0.1 \%$ and its frequency in CHDs was $0.2 \%$.

Egbe et al. ${ }^{[11]}$ found that pulmonary stenoses constituted $6.6 \%$ of all CHDs. The prevalence of pulmonary stenosis was $1.1 \%$ in our study, since only selected individuals were included. In addition, pulmonary stenoses constituted $3.9 \%$ of the CHDs.

In a study by Ivanov et al. ${ }^{[21]}$ conducted in 2020, it was reported that $72.7 \%$ of the patients with aortic stenosis were males. In our study, $77.8 \%$ of the patients with aortic stenosis were males.

Egbe et al. ${ }^{[1]}$ reported that the frequency of coarctation of the aorta in CHDs was $2.6 \%$. In our study, coarctation of the aorta constituted $0.8 \%$ of all CHDs. 
In a study conducted by Güven et al. ${ }^{[22]}$ in $2006,15.7 \%$ of the patients admitted to the neonatal unit had cyanotic CHDs. In our study, $0.4 \%$ of the subjects had cyanotic CHD and $1.6 \%$ of all CHDs were constituted by cyanotic CHDs. CHD surgery is not performed in our hospital. These patients are generally diagnosed before birth and their birth takes place in hospitals that is suitable for this surgery. This is the reason why the frequency of cyanotic heart diseases is low in our study.

There was some limitations in our study. First of all this is a single-center and a retrospective study. The reason of the high prevalence of CHDs in our study compared to the literature is that the study individuals were selected. In addition, it is often difficult to differentiate ASD and PFO in echocardiography at early stages of life because they cry a lot. Further studies are needed to determine the prevalence of CHDs in the population.

\section{CONCLUSION}

In conclusion; in the present study, nearly one-fourth of the subjects who underwent echocardiographic examination at the pediatric cardiology outpatient clinic had mild to severe CHDs. Most of the subjects with CHD were 0-1 month old. Conducting detailed echocardiographic examination on newborns referred to the pediatric cardiology department within the first month of life would enable detecting particularly CHDs with left-to-right shunt and cyanotic CHD. The early detection of these patients enables a more accurate route in follow-up and treatment.

\section{ETHICAL DECLARATIONS}

Ethics Comittee Approval: The study was obtained from the Ethics Committee of Necmettin Erbakan University Meram Faculty of Medicine with decision no. 2015/224.

Informed Consent: Written informed consent was obtained from all participants who participated in this study.

Status of Peer-review: Externally peer-reviewed.

Conflict of Interest Statement: The authors have no conflicts of interest to declare.

Financial Disclosure: The authors declared that this study has received no financial support.

Author Contributions: All of the authors declare that they have all participated in the design, execution, and analysis of the paper, and that they have approved the final version.

\section{REFERENCES}

1. Tennant PW, Pearce MS, Bythell M, Rankin J. 20-year survival of children born with congenital anomalies: a population-based study. Lancet 2010;375:649-56.

2. Posch MG, Perrot A, Berger F, Ozcelik C. Molecular genetics of congenital atrial septal defects. Clin Res Cardiol 2010;99:137-47.
3. Marelli AJ, lonescu-Ittu R, Mackie AS, Guo L, Dendukuri N, Kaouache M. Lifetime prevalence of congenital heart disease in the general population from 2000 to 2010. Circulation 2014;130:749-56.

4. Ergün Ç. Konjenital Kalp Hastalıkları. Turkiye Klinikleri J Int Med Sci 2006;2:51-9.

5. Özkutlu S, Günal N. Türkiye'de doğumsal kalp hastalıklarıprevalans, tanıdaki sosyoekonomik ve kültürel problemler, yeni tanı metodlarının uygulanabilirliği, çözümler. Turkiye Klinikleri J Cardiol 2003;16:369-71.

6. Zan S, Yapıcıoğlu H, Erdem S ve ark. Çukurova Üniversitesi Tıp Fakültesi Hastanesi yenidoğan yoğun bakım ünitelerinde son beş yılda izlenen konjenital kalp hastalarının retrospektif incelenmesi. Çocuk Sağlığı ve Hastalıkları Derg 2015;58:7-16.

7. Park MK. Specific Congenital Heart Defects. In:Park MK, editor. Pediatric Cardiology of Practitioners. 6th ed. Philadelphia: Elsevier Sounders 2014. p. 155-320.

8. Sağın Saylam G. Ventriküler septal defektlerde ekokardiyografik değerlendirme. Türk Kardiyol Dern Arş 2006;34:110-25.

9. van der Linde $D$, Konings $E E$, Slager $M A$, et al. Birth prevalence of congenital heart disease worldwide: a systematic review and metaanalysis. J Am Coll Cardiol 2011;58:2241-47.

10. Marelli AJ, Mackie AS, Ionescu-Ittu R, Rahme E, Pilote L. Congenital heart disease in the general population: changing prevalence and age distribution. Circulation 2007;115:163-72.

11. Egbe A, Uppu S, Lee S, Stroustrup A, Ho D, Srivastava S. Temporal variation of birth prevalence of congenital heart disease in the United States. Congenit Heart Dis 2015;10:43-50.

12. Kula S, ÇevikA, OlguntürkFR, Tunaoğlu FS, Oğuz AD, Illhan MN. Distribution of congenital heart disease in Turkey. Turk J Med Sci 2011;41:889-93.

13. Webb G, Gatzoulis MA. Atrial septal defects in the adult recent progress and overview. Circulation 2006;114:1645-53.

14. Lindsey JB, Hillis LD. Clinical update: atrial septal defect in adults. Lancet 2007:369:1244-6.

15. Holst LM, Kronborg JB, Jepsen JRM, et al. Attention-deficit/hyperactivity disorder symptoms in children with surgically corrected ventricular septal defect, transposition of the great arteries, and tetralogy of fallot. Cardiol Young 2020;13:1-8. doi: 10.1017/S1047951119003184.

16. Penny DJ, Vick GW. Ventricular septal defect. Lancet 2011;377:1103-12.

17. Baspinar O, Karaaslan S, Oran B, Baysal T, Elmaci AM, Yorulmaz A. Prevalence and distribution of children with congenital heart diseases in the central Anatolian region, Turkey. Turk J Pediatr 2006;48:237-43.

18. Kozik D. et al. Patent Ductus Arteriosus. In: Munoz R, Morell V, da Cruz E, Vetterly C, da Silva J. (eds) Critical Care of Children with Heart Disease. Springer, Cham. 2020. p. 145-54.

19. Kaufman J. et al. Complete Atrioventricular Septal Defects. In: Munoz R, Morell V, da Cruz E, Vetterly C, da Silva J. (eds) Critical Care of Children with Heart Disease. Springer, Cham 2020. p.177-89.

20. Ho ML, Bhalla S, Bierhals A, Gutierrez F. MDCT of partial anomalous pulmonary venous return (PAPVR) in adults. J Thorac Imaging 2009;24:8995.

21. Ivanov Y, Drury NE, Stickley J, et al. Strategies to minimise need for prosthetic aortic valve replacement in congenital aortic stenosis-value of the ross procedure. Semin Thorac Cardiovasc Surg 2020;S10430679(20)30030-7. doi: https://doi.org/10.1053/j.semtcvs.2020.02.015.

22. Güven $H$, Bakiler AR, Kozan M, Aydınlıoğlu H, Helvacı M, Dorak C. Yenidoğan servislerinde konjenital kalp hastalıkları. Çocuk Sağlığı ve Hastalıkları Derg 2006;49:8-11. 